\title{
透過型電子顕微鏡におけるモアレ縞
}

\author{
竹口雅樹 $1, *$ ・杉山直之 1,2 \\ ${ }^{1}$ 物質・材料研究機構電子顕微鏡ステーション 遥305-0047 茨城県つくば市千現 1-2-1

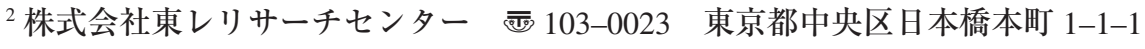 \\ MTTLIFE 日本橋本町ビル
}

（2018 年 8 月 5 日受付；2018 年 10 月 5 日掲載決定）

\section{Moire Fringes in Transmission Electron Microscopy}

\author{
Masaki TAKeguchi ${ }^{1, *}$ and Naoyuki SugiYama ${ }^{1,2}$
}

${ }^{1}$ Transmission Electron Microscopy, National Institute for Materials Science, 1-2-1 Sengen, Tsukuba, Ibaraki 305-0047

${ }^{2}$ Toray Research Center Inc., 1-1-1 Nihonbashi-honcho, Chuo-Ku, Tokyo 103-0023

(Received August 5, 2018 ; Accepted October 5, 2018)

\begin{abstract}
Moire fringes are observed when two (or more) crystal lattices are interfered in transmission electron microscopy (TEM). Typical application is the evaluation of epitaxial films grown on a substrate, in where their crystallographic orientation relationship could be investigated. Visualization of defects distribution using Moire fringes are also useful. Sometimes Moire fringes between crystal and digital pixel lattices are intentionally formed to visualize a strain map. In the present paper, some of those applications are introduced.
\end{abstract}

KEYWORDS : transmission electron microscopy, Moire fringe, epitaxial film, defect, strain

\section{1. は じめ に}

複数の縞パターンを重ね合わせた時, それらの周期の ずれによって生じる縞模様をモアレ縞と呼ぶ。透過型電 子顕微鏡法（TEM）では, 複数の結晶格子の干渉によ ってしばしばモアレ縞がみられる。これを利用して基板 結晶上のエピタキシャル膜の方位関係や界面整合の評価 にしばしば用いられる。また結晶内の欠陥など周囲の結 晶格子と欠陉部分の結晶格子のずれによってもモアレ縞 が生じるため, 欠陥評価にも用いられる。また結晶内の 歪や欠陥分布を容易に可視化するために参照格子をデジ タルに作って重ね合わせる場合もある。走査型透過電子 顕微鏡法（STEM）の場合は電子ビーム走査間隔と結晶 像との間でも周期や角度の違いに応じたモアレ縞が生じ る。本論文では，これらの事例について簡単に紹介す る。

*E-mail : takeguchi.masaki@nims.go.jp

\section{2. 結晶格子像によるモアレ}

Fig. 1 （a）は 2 種類の格子間隔 $d_{1}, d_{2}$ の格子縞が平行 に重なる場合, 式（1）で示される間隔 $D$ のモアレ縞 がこれらの格子と同じ方向に現れる。このようなモアレ は平行モアレと呼ぶ。

$$
D=d_{1} d_{2} /\left(d_{1}-d_{2}\right)
$$

一方, Fig. 1 (b) のように格子間隔 $d$ が同じで，わず かに角度 $\theta$ だけ回転している場合, 式（2）で示され るモアレ縞が 2 つ格子縞の方向の鈍角の 2 等分線方向 に現れる。このようなモアレは回転モアレと呼ぶ。

$$
D=d / 2 \sin (\theta / 2) \fallingdotseq d / \theta
$$

また，格子間隔が異なり，回転もしている場合は，式 （３）のように上記 2 種類の混合として

$$
D=d_{1} d_{2} /\left(\left(d_{1}-d_{2}\right)^{2}+d_{1} d_{2} \theta^{2}\right)^{0.5}
$$

なる間隔のモアレ縞が現れる。 
(a)

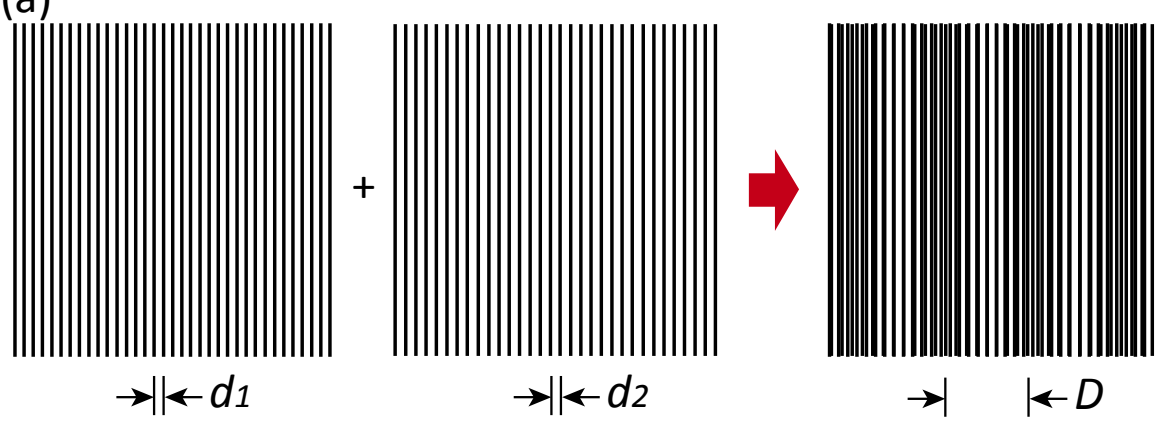

(b)
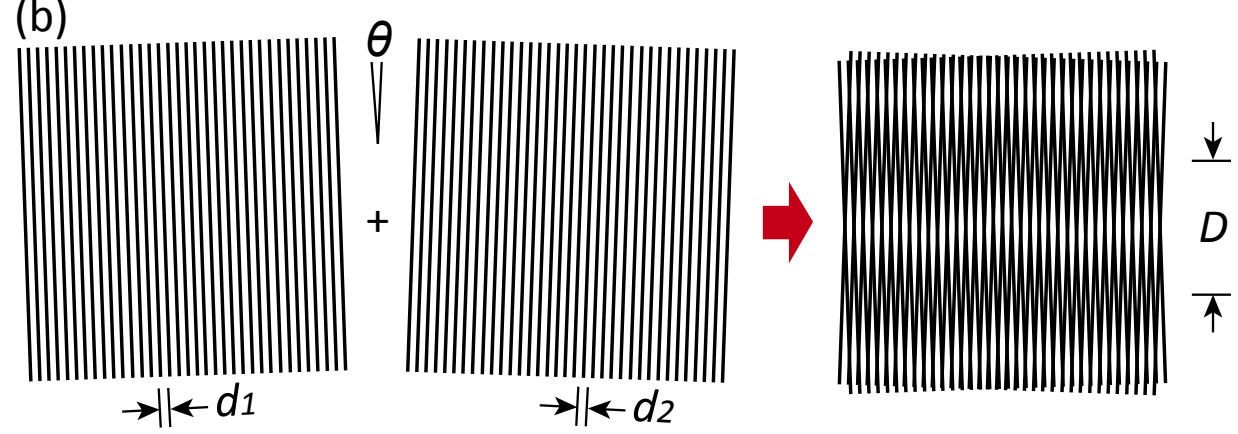

Fig. 1. (color online). (a) Parapel and (b) rotational moire fringes.

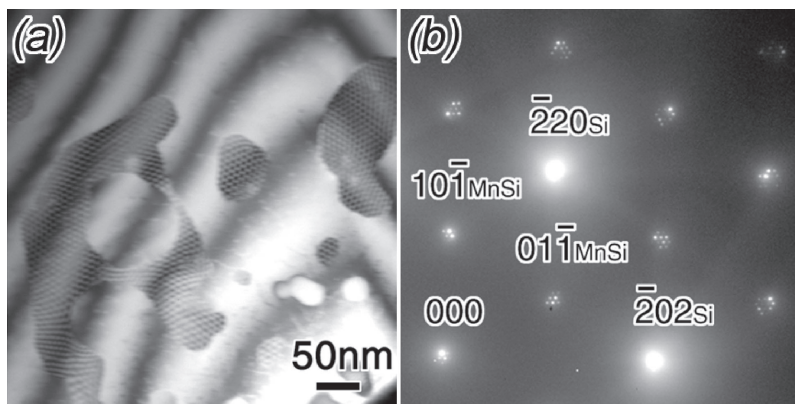

Fig. 2. (a) TEM image of incommensurate manganese silicide islands on $\mathrm{Si}(111)$ and (b) a part of electron diffraction pattern from an area of (a).

\section{3. 透過型電子顕微鏡におけるモアレ縞を応用 した解析例}

\section{$3.1 \mathrm{Si}(111)$ 上エピタキシャル成長 $\mathrm{MnSi}$ アイランド の観察例}

Fig. 2 は，超高真空内で $\mathrm{Si}(111)$ 基板上に室温で $\mathrm{Mn}$ を 平均膜厚 $15 \mathrm{ML}$ 蒸着した後, 大気にさらすことなく超 高真空透過型電子顕微鏡 JEM-2000VF に搬送し，TEM 内で $400^{\circ} \mathrm{C}$ でのアニールを行うことによって形成された シリサイド $(\mathrm{MnSi})$ アイランドの明視野 TEM 像および 電子線回折パターンの一部である ${ }^{1)}$ 。 MnSi は $\mathrm{Si}(111)$ 状 にエピタキシャルに成長し，(111) $)_{\mathrm{Si}} / /(111)_{\mathrm{MnSi}}, \quad[-101]_{\mathrm{si}} / /$ [-12-1 $]_{\mathrm{MnSi}}$ なる方位関係を持つが，格子間隔がそれぞれ

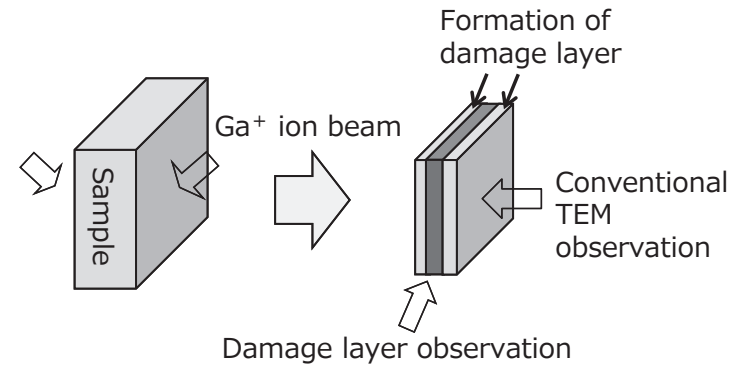

Fig. 3. Concept of damage layer formation by ion irradiation.

$0.193 \mathrm{~nm}, 0.186 \mathrm{~nm}$ とわずかに異なるため, このずれに 伴うモアレ縞 (平行モアレ) が観察されている。小さい MnSi アイランドは平行モアレが 3 方向に観察されてい るが，大きい MnSi アイランドはモアレ縞が歪んでお り，上記のような方位関係に乱れが生じていることが分 かる。このようにモアレ縞は TEM を用いた基板結晶上 のエピタキシャル膜の方位関係や界面整合の評価法とし てょく用いられる。なお，Si 基板部分にみえる縞は等厚 干渉縞である。

\section{2 FIB による加エダメージの検出}

$\mathrm{TEM} / \mathrm{STEM}$ 観察のための薄膜試料作製に広く用いら れている収束イオンビーム装置（FIB）は，非常にスル ープット良く加工が行える反面，イオンビームの衝突に よる加工ダメージが生じて像にアーティファクトが生じ ることが問題視されていた（Fig. 3 参照，現在は，低加 


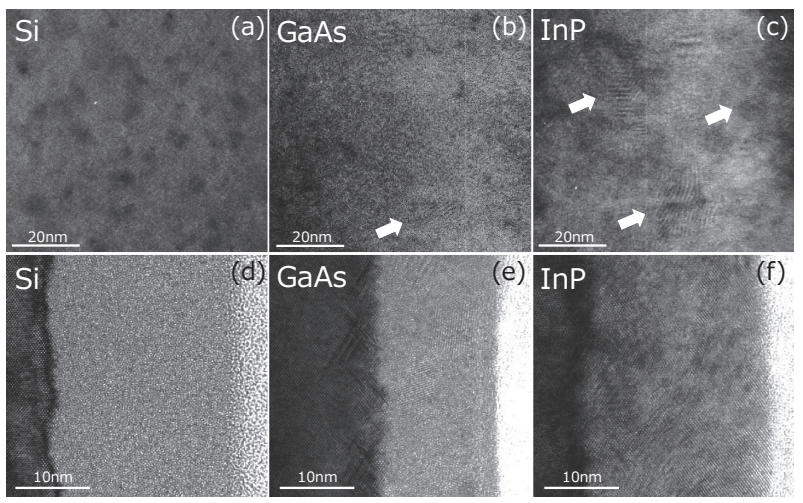

Fig. 4. TEM images of a damage layer of several semiconductor materials. (a)-(c) are taken from conventional TEM observation direction and (d)-(f) are vertical to them for detecting inside damage layer.

速加工や後処理により劇的に改善されてきた)。半導体 材料の中では，Si では主にこのダメージ層は非晶質化で あるが, 化合物半導体のような, 低融点元素およびイオ ンビームに対するスパッタレートが大きく異なる元素が 共存する材料では, 溶融による再付着, 結晶欠陥の生成 などが認められ，TEM 像の像質低下に対する影響が顕 著である。

Fig. 4 に加速電圧 $30 \mathrm{kV}$ で加工した $\mathrm{Si} ， \mathrm{GaAs}$ および $\mathrm{InP}$ の TEM 写真を示す。 $\mathrm{Si}$ では直径 $5 \mathrm{~nm}$ 程度のやや海 島状のコントラスト分布が観察されるのみだが，化合物 半導体 2 種では様々な間隔・方向のモアレ縞が観察さ れ，特に InP では頻度が高いことがわかる。この材料間 の差異を明らかにするために同一サンプルの断面方向か らの観察を試みた。

この結果より，3サンプル共に結晶領域（左側の黒色 領域）とダメージ層（右側のグレー色領域）の界面に比 較的大きな凹凸が存在していることがわかる。一方，Si ではダメージ層内は一様に非晶質化しているのみである のに対し, GaAs では表面に結晶欠陥が形成され, ダメ ージ層には格子縞が観察される領域 (微結晶) が点在し ている。さらに, InPではほほ全域にわたってランダム に格子縞が観察されており, GaAs よりも微結晶の密度 が高いと言える。

上記のダメージ層の断面結果より, (1) Si で観察され たコントラスト分布は界面の凹凸を反映している，(2) GaAs，InPで観察されたモアレ縞はダメージ層内の微結 晶の存在を反映しているといえる。

$\mathrm{InP}$ は In の融点が低く (約 $\left.157^{\circ} \mathrm{C}\right)$ ，さらに $\mathrm{P}$ が選択 スパッ夕を受けやすいことが知られている。つまり，ダ メージ層は溶融・再結晶化の過程が反映されている可能
性が高い。GaAs も InP ほどではないが同様の現象を反 映していると推測される。

ここでは半導体材料に扔ける事例を示したが, その他 の結晶性材料についても，モアレ縞の有無が FIB 等によ る加工ダメージの大小を判断する基準の一つになると言 える。

\section{3. $3 \mathrm{GaN} / \mathrm{SiC}$ エピタキシャル構造におけるモアレ縞 の観察}

$\mathrm{GaN}$ は，その特性から光デバイスからパワーデバイ スまで広く応用が期待される材料であるが，その他の化 合物半導体のように良質で大口径の単結晶を作成するこ とが難しく, 通常は他の単結晶基板を用いてエピタキシ ヤル成長膜として得られたものを用いる。他方, $\mathrm{GaN}$ の格子定数 $(\mathrm{a}=0.318 \mathrm{~nm})$ に近く容易に単結晶基板が 得られる材料がなく, 現在はサファイアや $\mathrm{SiC}$ などを基 板に用いているが界面における格子ミスフィットに由来 する貫通転位が高密度で生じ，良質な単結晶膜を得るの は現在でも困難である。

ここでは， $4 \mathrm{H}-\mathrm{SiC}$ 基板（格子定数 : $\mathrm{a}=0.307 \mathrm{~nm}$ ）を 用いて作成した $\mathrm{GaN}$ 膜について, 界面に押けるエピ夕 キシャル性を評価するためにモアレ縞を利用した結果を 紹介する。

Fig. 5 （a）にここの試料の断面 TEM 写真を示す。基 板と $\mathrm{GaN}$ 膜界面を起点として表面方向に延びる黒線状 のコントラストが多数観察されるがこれらは転位であ る。この構造の界面近傍を詳細に評価するため, 界面を 含む領域，および界面を含まない $\mathrm{GaN}$ 膜領域をそれぞ れサンプリングし， Plane-view 観察を実施した。

界面を含む領域では，ほほ正六角形状のコントラスト （Fig. 5（d）参照）が観察される一方で，GaN 膜内では 線状のコントラストのみが観察される。後者は断面 TEM 像にも認められる転位のコントラストである。

電子回折パターンとの比較から, 界面を含む領域で観 察される格子状のコントラストは, $\mathrm{GaN}$ および $\mathrm{SiC}$ の \{11-20\} 面に平行に出現していることが分かった。また, 電子回折パターンにおいては，基本格子反射の近傍に高 次の衛星反射が存在していることが確認されるが （Fig. 5 (e) の右肩部に拡大図を示す)，これは電子の多 重回折㧍よび基板 /エピ膜間の格子定数・結晶方位の差 異に起因するものである。この衛星反射が対物絞り内に 含まれた状態で結像されたことで，今回のようなモアレ 縞が可視化されている。

Fig. 6 に高倍率での格子像観察結果を示す。この観察 結果からも，六角格子状のモアレ縞と結晶格子面が 90 度（30 度）回転していることがわかる。また，この観 察サンプル内には，奥行き方向に $\mathrm{GaN}$ 膜と $\mathrm{SiC}$ 基板両 

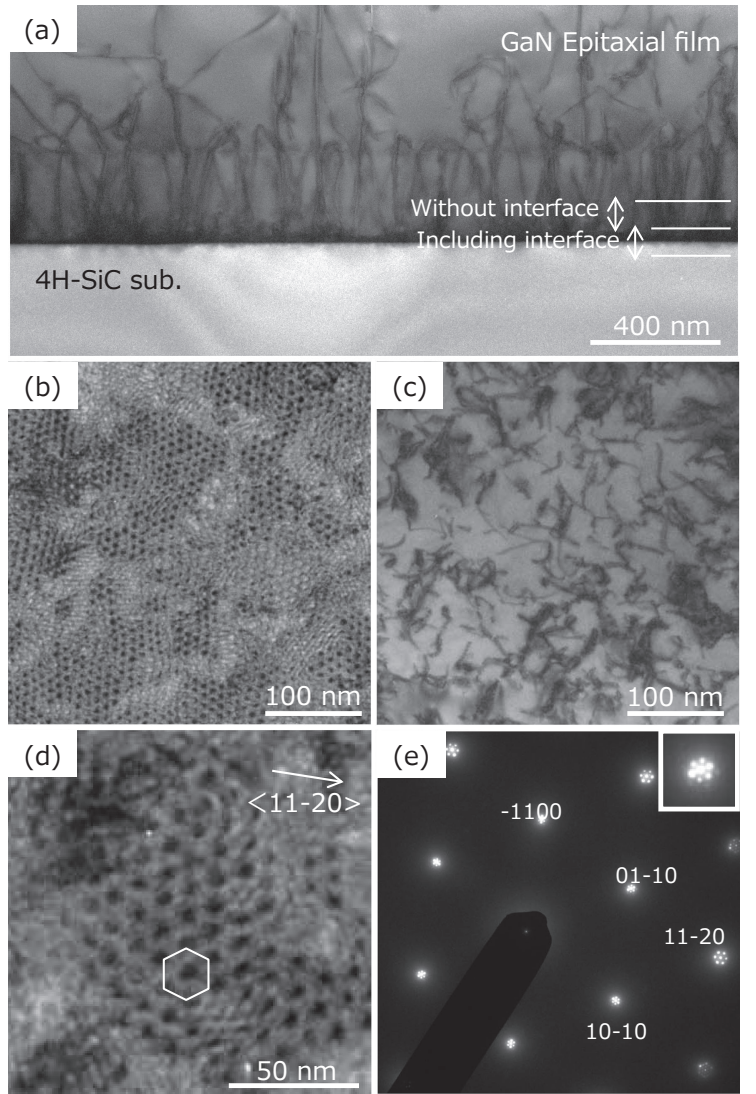

Fig. 5. TEM micrograph of $\mathrm{GaN}$ epitaxial film on $4 \mathrm{H}-\mathrm{SiC}$ substrate. (a) Cross sectional image, (b) plane-view image taken from area including interface, (c) plane-view image taken from GaN film near interface, (d) enlarged image of central area of (b), (e) selected area electron diffraction pattern corresponding to (b).
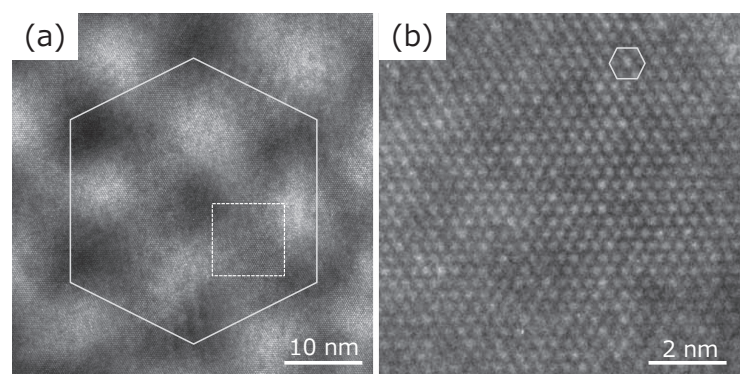

Fig. 6. High-resolution TEM micrograph of inside of large hexagonal moire fringe. (b) Corresponds to white square in (a).

者を含むが，モアレ縞の原因となっている格子面の僅か なずれは，この像中で確認することは困難である。

一連の観察結果より，今回観測されたモアレ縞は，そ の方位から $\mathrm{SiC}$ 基板と $\mathrm{GaN}$ 膜の僅かな結晶方位のずれ によって生じた回転モアレが主成分と思われる。そこで 基板 /エピ膜間の回転角について, 簡単な解析を実施し てみた。
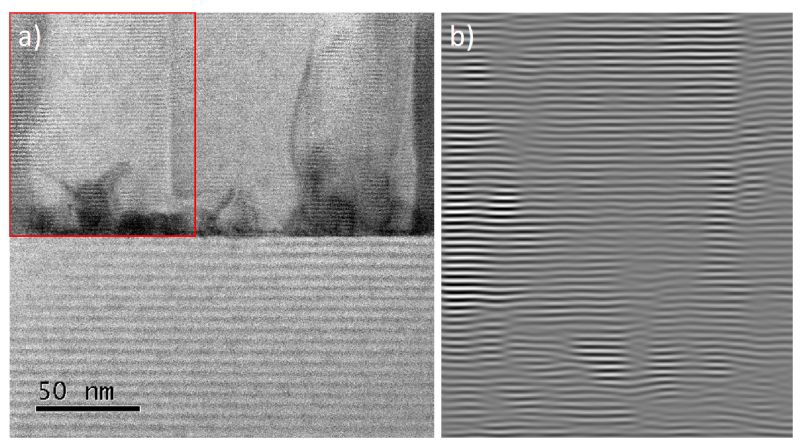

Fig. 7. (color online). (a) Scanning Moire fringe image formed by interference between scanning grating and sample's lattice spacing and (b) inverse Fourier-filtered image of the area in red-rectangle in (a).

Fig. 6 （a）から，モアレ縞の間隔を見積もると約 15 $\mathrm{nm}$ となる。一方で, 今回の系は, 格子面間隔も異なり, かつ回転しているため, 回転角の導出には, 混合系であ る前出の式（3）に代入し, $\mathrm{GaN}$ と $\mathrm{SiC}$ の (10-10) 面の 格子面間隔 $(\mathrm{GaN}: 0.2754 \mathrm{~nm}, \mathrm{SiC}: 0.2669 \mathrm{~nm})$ を用い て計算すると，傾斜角 $\theta=1.47^{\circ}$ と算出することができ る。

このように，モアレ縞を利用することで，接合界面に おける基板とエピタキシャル膜の僅かな結晶方位のずれ を算出することができる。

\section{4 STEM Moire 法による結晶性評価}

これまで結晶同士の干渉によるモアレ縞の例を紹介し てきたが，ここでは結晶（格子縞）とデジタルな画素格 子との干渉の応用例を紹介する。

Fig. 7 (a) は, サファイア基板上に成長させた AlN 膜の断面試料を円環暗視野 (High angle annular dark field；HAADF）STEMにより観察したものである。観察 する結晶の格子間隔に近い走査間隔になるように倍率を 調整することで, STEM の電子ビーム走查間隔と結晶像 との間の周期や角度の違いに応じたモアレ縞が生じる が，この場合は，サファイアおよび AlN のC 面を走査 方向と概ね平行にしており, 平行モアレが観察されてい る。サファイア基板部分ではモアレ縞は歪なく水平方向 に平行に並んでいる。Fig. 7 (b) は（a）の赤枠内の逆 FFT 像であり，モアレ縞を明暸化している。これにより AIN 膜内において欠楩に扔ける歪の状況が良くわかる。 このように STEM 画像のみならず TEM 画像でも格子像 を何らかの参照縞を干渉させることで歪を容易に可視化 することが可能となるので, 半導体デバイスの歪や成長 膜の欠陥分布の評価に有力なツールとして用いられてい $3^{2,3)}$ 。 
4. ま と め

透過型電子顕微鏡において，モアレ縞を使った応用例 をいくつか紹介した。歪や久陥は低空間周波数な対象で あるため, 高空間周波数である結晶格子そのものを使う よりもモアレ縞を使ったほうが広範囲にわたる歪や久陥 分布を精度よく評価できる。そのため, 結晶同士のモア レ縞を有効に利用してきたが，最近ではデジタルな処理 が容易になってきたため, 結晶格子縞とデジタルな画素 格子との干渉をコンピューター上で形成し, 可視化する ことも行われるようになってきている。

\section{文献}

1) Q. Zhang, M. Takeguchi, M. Tanaka and K. Furuya : J. Cryst. Growth 237-239, 1956 (2002).

2) S. Kim, S. Lee, Y. Oshima, Y. Kondo, E. Okunishi, N. Endo, J. Jung, G. Byun, S. Lee and K. Lee : Appl. Phys. Lett. 102, 161604 (2013).

3) Q.H. Wang, S. Ri, H. Tsuda, M. Kodera, K. Suguro and N. Miyashita : Nanotechnology 28, 455704 (2017). 